\title{
Translational research in testicular migration
}

\author{
Luciano A. Favorito ${ }^{1,2}$ \\ ${ }^{1}$ Unidade de Pesquisa Urogenital - Universidade do Estado de Rio de Janeiro - Uerj, Rio de Janeiro, RJ, Brasil, \\ ${ }^{2}$ Serviço de Urologia, Hospital Federal da Lagoa, Rio de Janeiro, RJ, Brasil
}

\section{COMMENT}

One of the most important research studies of the Urogenital Research Unit is about Testicular Migration. In the interesting paper of Logsdon and Collegues of our research group (1) we can observe a review about the role of the abdominal wall in testicular migration process during the human fetal period. Testicular descent is a complex process of relevant importance for the comprehension of cryptorchidism. There are several anatomic and hormonal factors involved in the testicular migration process (2-4). In present paper (the cover of this edition of Int Braz J Urol) the authors concluded that the abdominal pressure wound is an auxiliary force in testicular migration. Patients with abdominal wall defects are associated with undescendend testis in more than $30 \%$ of the cases probably due to mechanical factors; the Prune Belly Syndrome has anatomical changes in the anterior abdominal wall that hinder the increase of intra-abdominal pressure which could be the cause of cryptorchidism in this syndrome.

\section{CONFLICT OF INTEREST}

None declared.
Luciano A. Favorito, MD, PhD

Unidade de Pesquisa Urogenital da Universidade do Estado de Rio de Janeiro - UERJ,

Rio de Janeiro, RJ, Brasil E-mail: lufavorito@yahoo.com.br

\section{REFERENCES}

1. Logsdon NT, Sampaio FJB, Favorito LA. The role of intraabdominal pressure in human testicular migration. Int Braz J Urol. 2021;47:36-44.

2. Favorito LA, Costa SF, Julio-Junior HR, Sampaio FJ. The importance of the gubernaculum in testicular migration during the human fetal period. Int Braz J Urol. 2014;40:722-9.

3. Favorito LA, Sampaio FJ, Javaroni V, Cardoso LE, Costa WS. Proximal insertion of gubernaculum testis in normal human fetuses and in boys with cryptorchidism. J Urol. 2000;164(3 Pt 1):792-4.

4. Sampaio FJ, Favorito LA, Freitas MA, Damião R, Gouveia E. Arterial supply of the human fetal testis during its migration. J Urol. 1999;161:1603-5.

ARTICLE INFO

Luciano A. Favorito http://orcid.org/0000-0003-1562-6068

Int Braz J Urol. 2020; 46: 45

Submitted for publication: September 10, 2020

Accepted:

September 15, 2020 